\title{
The Impact of Sofokrom Quarry on River Anankwari
}

\author{
Peter Mensah Abroampah ${ }^{1}$, Ebenezer Boakye², Peter Paa-Kofi Yalley ${ }^{3}$ \\ ${ }^{1}$ Takoradi Technical Institute, Ghana \\ ${ }^{2}$ Civil Engineering Department, Takoradi Polytechnic, Ghana \\ ${ }^{3}$ Faculty of Technical Education, University Of Winneaba, Ghana
}

\begin{abstract}
This study assessed the effect of quarry activity on ANANKWARI river in the shama Ahanta East of Western Region. Questionnaire administration and observations were used for primary data collection whilst rainfall and hydrological data were gathered to aid the study. Water quality analysis of samples from upstream and downstream were conducted. Data was statistically analyzed and with reference to WHO guidelines for drinking water, analysis was made. The study identified that the intense operation of quarry in the catchment since 2011 has resulted in the decrease of average annual discharge of $574796 m^{3}$ in 2009 to $480252 m^{3}$ in 2012. Physical and chemical parameters of all samples in the downstream showed appreciably statistically different values from respective upstream sampling locations. Most of the physico-chemical parameters such as pH, turbidity, color, temperature etc. of the downstream did not meet the WHO standards. This pollution attributed to quarry operation has affected downstream users causing skin diseases and chronic coughs for consuming the raw water. Public awareness with respect to the need to boil and filter the downstream water before drinking or bathing is significant. A hydro-meteorological monitoring network station must be established within the sub-catchment area to consistently determine the culminated effect.
\end{abstract}

Keywords: Quarry activities, Anankwari river, water quality parameters, discharge, catchment

\section{Introduction}

Quarry activities in and around water bodies have great influence on the water resource in that it can substantially modify the routing of discharge and therefore water quality may be degraded(Gunn and Hobbs, 1999). Quarry includes a range of processes, such as blasting, grinding and transportation thus solid materials in the form of smoke, dust and also vapour are generated, released and suspended over long period in the atmosphere. These particulate matters in the air are capable of being transported to nearby water bodies thereby polluting it(UNEP, 1999). These pollutants are seen as non-point sources as they can enter the river system through surface or groundwater and it is well known that sedimentation can increase through site runoff ( Kondolf et al., 1994). The non-point sources are eventually spread out to pin point the exact origin of pollutants. Because of this, suspended solids becomes an important factor in determining water quality as there are a number of factors influencing them.

Quarry discharge can arise from different aspects of rock extraction, making it possible to provide an effect on river systems both physically(with changes in suspended sediments) and chemically(changes in river $\mathrm{PH}$ ) (Musah, 2009). It can also destroy in-stream and river reserve habitats for a broad range of species as well as indirectly impair the functioning of the aquatic ecosystem(Martin, 2003). Besides, increased stream turbidity as a result of quarrying operations may temporarily reduce light penetration within the river, which will impact rates of photosynthesis and therefore primary production rates.

Water is an indispensable natural resource which is vital for the sustainability of life. Virtually all of human uses require fresh water which constitutes only three percent of the water on the earth, the rest being salt water (USGS, 2002). However, the world's supply of clean, fresh water is steadily decreasing. Demand for water already exceeds supply as the world population continues to rise. Nonetheless, Drinking or potable water has to meet some health standards set by the World Health Organization. Three parameters are used for assessing the quality of drinking water: Physical, Chemical and Biological parameters (WHO, 2010). Physical parameters including Temperature, $\mathrm{pH}$, Electrical Conductivity, Suspended Solids (SS), Dissolved Oxygen (DO), and Total Dissolved Solids (TDS) affect the aesthetic quality and taste of drinking water. Chemical parameters include the presence of major cations and an ions, arsenic, heavy metals (chromium, lead, cadmium, etc) and trace organic compounds (animal wastes) and poly atomic ions (nitrates, sulphates, carbonates, etc). These tend to pose chronic health risks through build up, some causing fatalities. The most common Biological parameters are from pathogens like bacteria viruses (Vibrio cholerae), protozoa and helminth(US EPA, 2012). When these compositions are altered beyond the permissible levels directly or indirectly by human activities, the water is said to be polluted (Michaud, 1995) restricting the potential uses of the water (Kuma and Ewusi, 2009). In Ghana, there is growing public concern about the condition of fresh water. Mining activities are seriously impairing the available water resources in the face of limited supplies. According to Ghana Water Company, only one quarter of the residents in case study area (Sekondi-Takoradi Metropolis) receive a continuous water supply, whereas approximately $30 \%$ are provided for 12 hours each day, five days a week. Another $35 \%$ are supplied for two days each week. The remaining $10 \%$ who mainly live on the outskirts of the capital are completely without access to piped water (Water Aid, 2008). The situation is even worse in Accra, the Nation's Capital. 


\section{International Journal of Science and Research (IJSR) \\ ISSN (Online): 2319-7064}

Index Copernicus Value (2013): 6.14 | Impact Factor (2014): 5.611

Even though there is growing awareness of the environmental legacy of quarry mining activities it has been undertaken with little concern for the environment. Therefore the price we have paid for our everyday use of quarry stones has sometimes been very high. For instance, drilling records have revealed that on the average, about $20 \%$ of surface water drilled for domestic water supplies contain high concentrations of Manganese or ion, or both metal compounds above the Ghana Standards Board permissible limits of $0-0.1 \mathrm{mg} / \mathrm{L}$ (Manganese) and 0 $0.3 \mathrm{mg} / \mathrm{L}$ (ion) for domestic water supply in some regions in the country including Eastern, Greater Accra, Central, Northern, Ashanti, Volta and Western. Low PH (Water Acidity) levels are also associated with surface water in most of the geological formations in these regions (CWSA, 2004).

The Sofokrom quarry located within the catchment area of Anankwari river, the main water source that feeds the
Inchaban water works(i.e, main source of water supply for Sekondi-Takoradi Metropolis in the Western Region of Ghana) has been in existence for over 21 years with an intense activity since 2011 . The study aims at assessing the impact of this quarry on the Anankwari river with specific objectives as: 1. evaluating the activities of the quarry, 2 . determining the effect of the quarry on the river quantity and quality.

\section{Methodology}

\subsection{Description of Study Area}

The Anankwari River forms part of the Pra basin of the south western river system in Ghana. The river flows into and feeds the Ichaban reservoir as shown in fig. 1 . It is confined within latitudes $5^{\circ} 0^{\prime \prime} \mathrm{N}$ and $4^{\circ} 5^{\prime \prime} \mathrm{N}$. and longitudes $1^{\circ} 41^{\prime}$ and $1^{\circ} 40^{\prime} \mathrm{W}$.

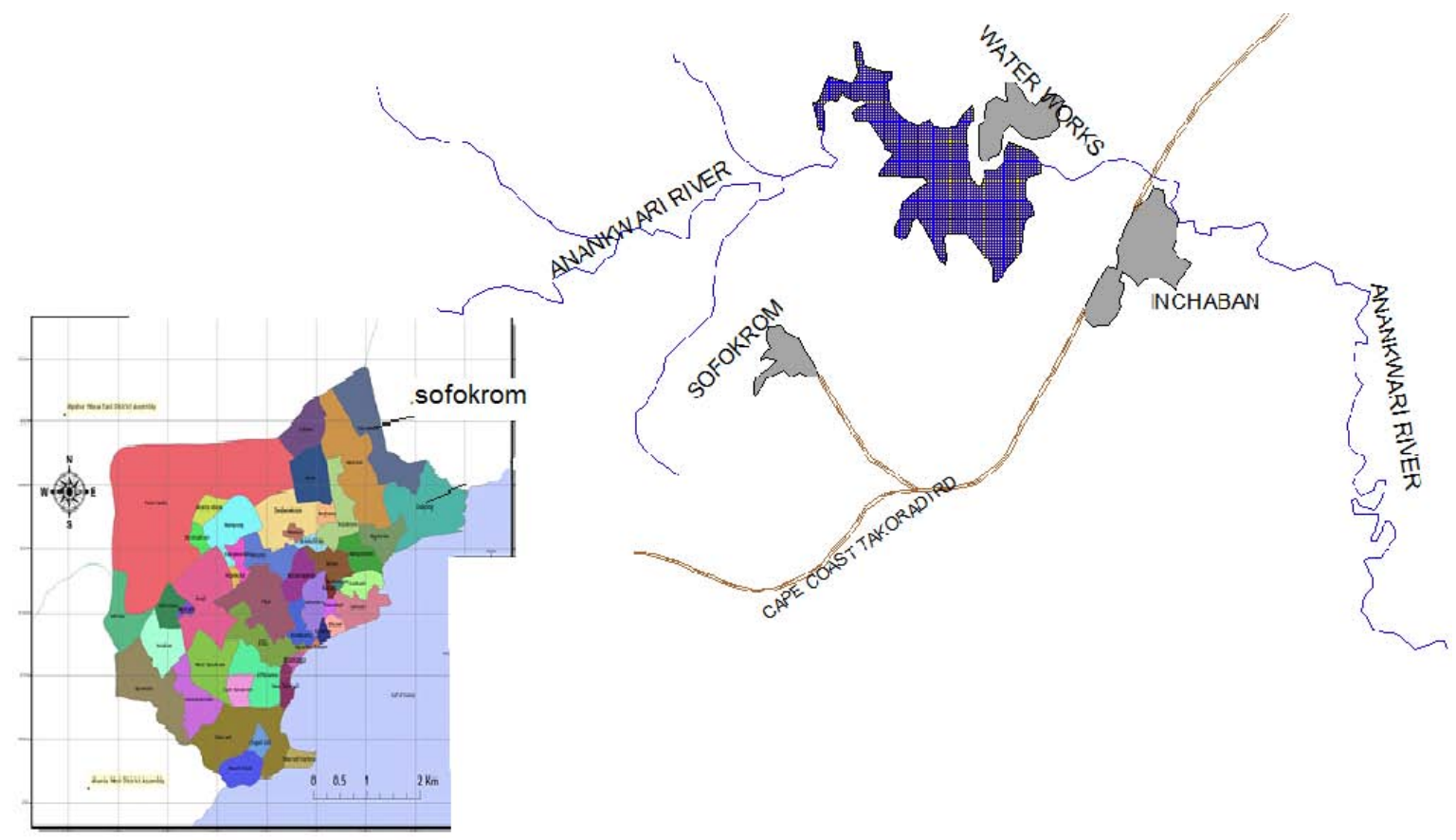

Figure 1: Location of the Anankwari river

\subsection{Experimental procedure and methods}

The study employed both quantitative and qualitative techniques in the collection of data. Both secondary and primary data were collected. The secondary data were the rainfall data obtained from Ghana Metrological Agency and river discharges from Ghana Hydrological Services. Field surveys involving interviews and questionnaire administration was adopted for the collection of primary data. In addition, water quality analysis of samples from the Anankwari river was conducted.

\section{Data Collection}

In conducting the interview, convenient sampling approach was used to select the respondents for the study. The selected respondents were two head teachers of the local basic schools, the Assemblymen of the electoral area, six school representatives from the two selected schools, the traditional chief and the queen mother in the immediate quarry catchment area. Again health workers of the catchment area were also interviewed. It must be noted that the selected group which mostly depends on the raw water for domestic activities were interviewed. Besides, Dozer operators and foremen were interviewed. The questionnaires intended to identify the methods of operation of the quarry firms and to ascertain the effect of the quarry activity on the river and the inhabitants in the catchment area.

\section{Water Quality Analysis}

Laboratory analysis was carried out on water samples collected from both the downstream and upstream of Anankwari river in the months of December, January and February. At each sampling point, a clean 1-litre polyethylene sample bottle was filled with water. This was, subsequently, used in the laboratory for offsite analysis. 


\section{International Journal of Science and Research (IJSR) \\ ISSN (Online): 2319-7064}

Index Copernicus Value (2013): 6.14 | Impact Factor (2014): 5.611

The water samples were kept at $4^{\circ} \mathrm{C}$ in ice chest and transported to the laboratory of the field station of the Ghana water company Limited, Takoradi, on the same day of collection for analysis. Sampling bottles had appropriate labels on them and record was made of each bottle. The samples were refrigerated upon receipt in the laboratory to avoid external contamination or deterioration, until the time of the analysis. Parameters tested were: Turbidity, Colour, Suspended Solids, Alkalinity, Hardness, Manganese, PH, Chloride, dissolved solid. All the test conducted was in accordance to the WHO and Ghana Standard Board(GSB). The key equipments used are Turbidity meter, measuring cell, flask, multi meter, spectrophotometer, Erlenmeyer flask, pipette, and beakers. All the analysis were based on standard methods as appropriate to each water quality parameter, as prescribed in APHA(1998).

\section{Results}

Ninety eight percent of the questionnaires administered were received from respondents of varying demographic characteristics. The study revealed that existence of quarry activities in the area has been operating for more than 21 years with an intense activity since 2011 . The main method used in the quarry site is manual and blasting. All the respondents declared that the activities of the quarry have had effect on the river: That the quarry leave residue of chemicals in the river; dust from the quarry pollutes the water from the river resulting to the drying-up of the Anankwari river. Again, infectious diseases such as skin diseases and chronic cough has been predominantly contracted from bathing or drinking from the river. $82.2 \%$ of respondents also confirmed that the colour of the river has changed due to the quarrying activities within the Esipong and Sofokrom communities.

\section{Physicochemical Assessment of River Anankwari}

Table 1 shows the results of the water quality analysis conducted for both the upstream and downstream of the Anankwari river.

Table 1: Mean levels of water quality parameters for upstream and down stream

\begin{tabular}{|c|c|c|c|c|c|c|}
\hline & \multicolumn{2}{|c|}{ December } & \multicolumn{2}{|c|}{ January } & \multicolumn{2}{c|}{ February } \\
\cline { 2 - 7 } & Upstream & Down stream & Upstream & Down stream & Upstream & Down stream \\
\hline $\mathrm{Ph}$ & 7.80 & 9.20 & 6.60 & 8.90 & 6.80 & 9.90 \\
\hline Colour & 12.50 & 24.90 & 15.90 & 25.90 & 19.70 & 30.60 \\
\hline Temperature & 25.50 & 28.60 & 25.30 & 26.50 & 25.30 & 29.50 \\
\hline TDS & 54.80 & 64.40 & 73.90 & 78.40 & 66.15 & 62.20 \\
\hline TSS & 68.50 & 61.25 & 56.74 & 74.20 & 54.67 & 87.50 \\
\hline Conductivity & 114.00 & 190.00 & 148.10 & 119.80 & 132.70 & 224.00 \\
\hline Turbidity & 7.45 & 7.90 & 12.83 & 16.62 & 5.26 & 15.56 \\
\hline Alkalinity & 201.20 & 260.00 & 210.32 & 256.10 & 219.10 & 569.00 \\
\hline Manganese & 0.94 & 0.6 & 0.5 & 1.3 & 0.4 & 1.2 \\
Chloride & 18.00 & 23.10 & 12.36 & 29.40 & 16.94 & 30.4 \\
Total hardness & 67.50 & 94.20 & 69.4 & 100.8 & 56.40 & 86.8 \\
\hline
\end{tabular}

The mean $\mathrm{pH}$ values at both the up and down streams of Anankwari river recorded within the three month period were $7.80,6.60$ and 6.80 for up streams and 9.20, 8.9 and 9.9 for down streams respectively. The downstream recorded the highest values for the water samples for the entire period than the upstream. Significant differences $(\mathrm{p}<$ 0.05 ) between at least two treatments means existed within the upstream and downstream sampled values. However there were no significant differences $(p>0.05)$ among the samples within the same stream for the three months period.

The colour determined for the sampled water from the respective upstream and downstream locations indicated that the samples from the downstream recorded the highest colour values throughout the three months. Colour of the upstream water samples was clear, slightly turbid and odour was unobjectionable. The mean colour from upstream ranged from 12.5 to $19.7 \mathrm{~Hz}$. The downstream also recorded a ranged of higher mean values of 24.9 to $30.6 \mathrm{~Hz}$. There was substantial variance $(\mathrm{p}<0.05)$ between at least two treatments means within the data.

The mean temperature determined for the samples from the respective location proved that the downstream water sampled recorded the highest mean temperature values. The temperatures of the upstream were in the range of 25.2 - $25.5^{\circ} \mathrm{C}$. The downstream water sampled recorded an average range of $26.5-29.5^{\circ} \mathrm{C}$. There was significant difference $(\mathrm{p}<$ 0.05 ) between the upstream and downstream mean values for the entire sample period.

Total suspended solids (TSS) recorded for the water from the Anankwari indicated that the downstream sampled water obtained the highest mean range of $61.25 \mathrm{mg} / 1$ to $87.5 \mathrm{mg} / \mathrm{l}$ as against upstream of mean range of $54.67 \mathrm{mg} / \mathrm{l}$ to 68.5 $\mathrm{mg} / \mathrm{l}$ during the three months period. There was significant differences $(p<0.05)$ between at least two treatments mean within the data.

Total Dissolved solids (TDS) recorded for the water from the Anankwari indicated that the downstream untreated water obtained the highest mean range of $54.8 \mathrm{mg} / 1$ to 73.9 $\mathrm{mg} / \mathrm{l}$ as against upstream of mean range $64.40 \mathrm{mg} / \mathrm{l}$ to 78.4 $\mathrm{mg} / \mathrm{l}$ of during the three months period. There was significant differences $(p<0.05)$ between at least two treatments mean within the data.

Alkalinity recorded from the Anankwari river indicated that the downstream water had the highest mean range of 256.10 $\mathrm{mg} / \mathrm{l}$ in January to $569.10 \mathrm{mg} / \mathrm{l}$ in February as against upstream of mean range of $201.2 \mathrm{mg} / \mathrm{l}$ in December to $219.10 \mathrm{mg} / \mathrm{l}$ in February. There was significant differences

\section{Volume 4 Issue 11, November 2015}




\section{International Journal of Science and Research (IJSR) \\ ISSN (Online): 2319-7064}

Index Copernicus Value (2013): 6.14 | Impact Factor (2014): 5.611

$(p<0.05)$ between at least two treatments mean within the data.

Manganese recorded for the water from the Anankwari indicated that the downstream untreated water obtained the highest mean range of $0.60 \mathrm{mg} / 1$ to $1.3 \mathrm{mg} / \mathrm{l}$ as against upstream of mean range $0.4 \mathrm{mg} / \mathrm{l}$ to $0.94 \mathrm{mg} / \mathrm{l}$ of during the three months period.

The average chloride level recorded from the Anankwari river indicated that the downstream recorded the highest mean range values from $23.0 \mathrm{mg} / \mathrm{l}$ in December to $30.0 \mathrm{mg} / \mathrm{l}$ in February as against upstream of mean range from 12.4 $\mathrm{mg} / \mathrm{l}$ in January to $18.0 \mathrm{mg} / \mathrm{l}$ in December during the three months . There was significant differences $(\mathrm{p}<0.05)$ between at least two treatments mean within the data

The total hardness recorded for the water from the Anankwari indicated that the downstream water recorded the highest mean range from $86.8 \mathrm{mg} / 1$ in February to 100.8 $\mathrm{mg} / \mathrm{l}$ in January as against upstream of mean range from $56.4 \mathrm{mg} / \mathrm{l}$ in February to $69.4 \mathrm{mg} / 1$ in January during the three months There was significant differences $(p<0.05)$ between at least two treatments mean within the data

Conductivity recorded for the water from the Anankwari showed that the downstream untreated water obtained the highest mean range of 119.8 to 224.0 as against upstream of mean range 114.10 to 132.7 during the three months period. There was significant differences $(p<0.05)$ between at least two treatments mean within the data.

Turbidity determined for the water from the respective locations indicated that the downstream untreated water recorded the highest mean values of 7.90, 16.62 and 6.66 against upstream of mean values of $7.45,12.83$, and 5.26 during the three months period. There was significant differences $(p<0.05)$ between at least two treatments mean within the data.

\section{Discharge of the Anankwari River}

Table 2: Discharge of the Anankwari river before and during quarry

\begin{tabular}{|l|c|c|c|}
\hline \multicolumn{2}{|c|}{ Discharge Before Quarry } & \multicolumn{2}{c|}{ Discharge During Quarry } \\
\hline Year & $\begin{array}{c}\text { Annual discharge } \\
\left(\mathrm{m}^{3}\right)\end{array}$ & Year & $\begin{array}{c}\text { Annual discharge } \\
\left(\mathrm{m}^{3}\right)\end{array}$ \\
\hline 2009 & 574796 & 2011 & 494837 \\
\hline 2010 & 504378 & 2012 & 480252 \\
\hline Average & 539587 & Average & 487544.5 \\
\hline
\end{tabular}

Table 2 illustrate the average annual discharge of river Anankwari for two-year period before and during. Average annual discharge before the quarry activities of the river was $\mathbf{5 3 9 5 8 7 \mathrm { m } ^ { 3 }}$ whilst the discharge during the activities was $\mathbf{4 8 7 5 4 4 . 5} \mathrm{m}^{3}$ showing a decline.

\section{Rainfall Pattern}

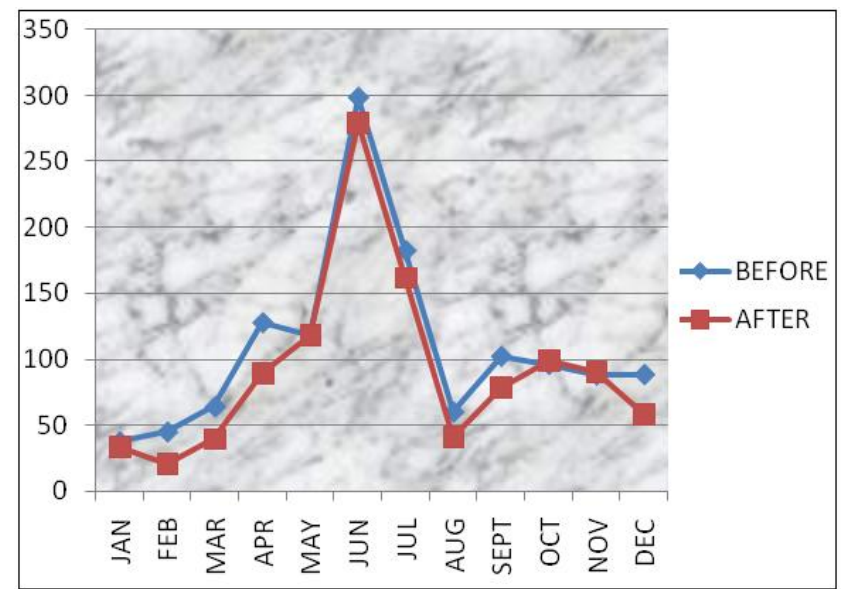

Figure 2: Rainfall Pattern before and after(during) quarry operation

The average monthly rainfall for the Sofokrom subcatchment two years before and after the establishment of the quarry operation is shown in figure 2.0. The result depicts a perfect normal distribution for a typical tropical rainforest area such as Ghana. Although the result generally depicts a gradual decrease in the rainfall, it does not show a clear trend in the decline. The average rainfall from February to April showed a difference of about 30 $\mathrm{mm} /$ month after the establishment of the quarry operation. The average rainfall for the month of May did not change two years after the operation of the quarry activities. It however decreased gradually and continuously from June through to September with an intensity of about 21 $\mathrm{mm} /$ month. It then remained constant from October to November and eventually decreased in December with an average intensity of about $30 \mathrm{~mm} / \mathrm{month}$.

\section{Discussion}

It is evident that the average annual discharge of the Anankwari river(Table 2) after the establishment and operation of active quarry is reduced. This confirms the respondents perception mentioned earlier. This reduction in the river discharge could surely be attributed to the activities of quarry as particulate matter in the form of smoke, dust and vapour are transported to nearby water bodies increasing sedimentation(UNEP, 1999 and Nisa,1997). Consequently, the reduced discharge will affect the volume of the Inchaban reservoir which supply water to Sekondi-Takoradi metropolis and its environs for consumption.

The operation of the quarry involves extensive clearing of vegetation in order to have access to the geological formation (quarry material). This activity can influence the average annual transpiration within the catchment area by reducing the humidity. The relative reduction in humidity might eventually reduce the average annual rainfall within the catchment area as depicted in fig.2. Moreover, since changes in climatic variables are long term it is evident that short term rainfall data cannot effectively show a significant impact of the operational activities of the quarry company. It is however recommended that a monitoring hydrological network station be established within the sub-catchment or 


\section{International Journal of Science and Research (IJSR) \\ ISSN (Online): 2319-7064}

Index Copernicus Value (2013): 6.14 | Impact Factor (2014): 5.611

basin to record these parameters for a time period of at least ten years.

The Physico-chemical parameters of both upstream and downstream is shown in Table 1 . The $\mathrm{pH}$ values of the upstream of Anankwari river was within the WHO acceptable limit whilst downstream was above. Water contamination as a result of quarry activities can have serious effect on living things, including man and animals (Armah et al.,2010) as it can affect Hydrogen ion concentration $(\mathrm{pH})($ Daniel, 2002). A change in $\mathrm{pH}$ in rivers as indicated by Morrison et al. (2001), could impair recreational uses of water, affect aquatic life and decrease the solubility of certain essential elements such as Selenium and increase harmful metals as Cadmium, Mercury and Aluminium.

Temperature is one of the important factors in environment since it regulates the various physico-chemical as well as biological activities (Kumar, 1996). The water temperature follows a diurnal variation, increases in day time and decreases during night. The temperatures of the upstream were in the range of $25.2-25.5{ }^{\circ} \mathrm{C}$. The downstream water sampled recorded an average range of $26.5-29.5^{\circ} \mathrm{C}$. This indicates that the downstream mean temperatures is above the WHO and Ghana EPA recommended standard (15 $25^{\circ} \mathrm{C}$ ) for drinking water. The high temperature recorded for the downstream may be due to high turbidity and conductivity value (suspended materials) in the stream caused by the quarry operations. Increase in temperature accelerates the chemical reactions in water and thereby reduces the solubility of gases and impart taste and odour to the water.

The downstream colour recorded a higher range of 24.9 $30.6 \mathrm{~Hz}$ which were above $15 \mathrm{~Hz}$ ( WHO recommended limit for no risk): a confirmation of the inhabitants response that the river colour changed since the operation actively began. This goes to indicate that the downstream water is not very suitable for drinking and will require high level of treatment. According to Karikari et al. (2006), increase in the colour of water in reservoirs results in increases in treatment cost. All the turbidity values recorded in the downstream do not meet the WRC and the WHO (2010) standard (5FTU) as it shows a higher level of turbidity. High turbidity levels in water causes problems with water purification processes such as flocculation and filtration, which may increase treatment cost. The high level of turbidity recorded in this study for the downstream water may have been strongly influenced by soil erosion and decay of organic matter from improper disposal of quarry activities within the catchment. The high turbidity could be due to the increased amount of precipitates in the water from corrosion as the amount of particulate matter (and thus turbidity) increases. Total dissolved solids (TDS) level at all the sampling sites was below the minimum WHO limit. These areas experienced low rainfall due to the dry season and probably there was not enough mineralization of the bedrock which could result in low concentration of mineral salts. According to Davies \& James(2001) both heavy rainfall and the consequent rapid erosion of soil and leaching of associated bedrock can dramatically raise the dissolved solids content in a river.

\section{Conclusion and Recommendations}

The average annual discharge of the river decreased from $574796 \mathrm{~m}^{3}$ in 2009 to $480252 \mathrm{~m}^{3}$ in 2012 and could be attributed to the quarrying of stones and sand in the catchment. The average rainfall is probably to be affected since quarry operation influences the average annual transpiration within the catchment area by reducing the humidity. The physical and chemical parameters of all sampled water in the downstream showed appreciably statistically different values from respective downstream sampling locations. Most of the physico-chemical parameters such as $\mathrm{pH}$, turbidity, colour, temperature, etc. of the downstream of the Anankwari river did not meet the WHO standards. This pollution can be attributed to contamination from quarry activities and the people of Sofokrom at the downstream has suffered from consuming the raw water. There is the need to educate the public on efficient water use methodologies and the intensification of the educational awareness as to how to handle and locally treat water for domestic use. In view of the importance of the Anankwari River which supply water to SekondiTakoradi metropolis and its environs there is a need to protect the ecosystem, stringent efforts should be made to, on regular basis, monitor the water quality of the river as well as the landscape in order to conserve the ecosystem. Also a monitoring hydro-meteor-logical Network station be established within the sub - catchment area to record hydrometeor-logical data consistently. The rules and regulation governing the operation of quarry activities must also be enforced.

\section{References}

[1] A.P.H.A., (1998). Standard Methods for Examination of Water and Waste Water. 20th Edition. American Public Health Association, Washington D.C.

[2] Armah, A., Obiri, S., Yawson, D.O., Papoe, A.N.M.(2010). Mining and Heavy metal pollution: Assessment of Aquatic Environments' in Tarkwa(Ghana) using multivariate statistical analysis. Journal of Environmental statistics, Feb, 2010, Vol. 1, issue 4

[3] Community Water and Sanitation Agency (2004). Strategic investment plan 2005-2015"

[4] Daniel, A. (2002). An Environmental pollution in Ghana. Accra: Ghana Publishing corporation.

[5] Davies, Y., \& James, S. (2001). Water Quality Impact Analysis. New York: Irwin/McGraw- Hill.

[6] Gunn, John, and Hobbs, S.L., (1999). Limestone quarrying: hydrogeological impacts, consequences, implications: in Drew, David, and Hötzl, Heinz, eds.: Karst hydrology and human activities - Impacts, consequences and implications, A.A. Balkema, pp. 192 201.

[7] Karikari, A. Y., \& Ansa-Asare, O. D. (2006). Physics chemical and microbial river of Ghana. West African Journal Ecological .Vol.4. pp 87 - 100.

[8] Kumar, O. A. (1996). Surface water resources. In water resources management study Information Building Design Block study. Niiconsult Accra Ghana Page $10-$ 32 . 


\section{International Journal of Science and Research (IJSR) \\ ISSN (Online): 2319-7064}

Index Copernicus Value (2013): 6.14 | Impact Factor (2014): 5.611

[9] Kuma, J.S. and Ewusi, A.(2009). Water Resources issues in Tarkwa municipality, south west Ghana, Ghana mining journal vol. pp 37-46.

[10] Kondolf, J. K., Bjarlund, G. and Nujlis, P.(1994). Future sustainable water use; Challenges and constraints, 151156.

[11] Martin. L. (2003). Effect of quarry on water bodies. New York: Macmillan Publishers.

[12] Morrison, M. A. S., Mwanga, K., \& Simoro, A. (2001). Impact assessment of industrial and sewage effluents on the water quality of receiving Marimba River in Harare, Zimbabwe: University publications.

[13] Michaud, J.P. (1995). A citizens guide to understanding and monitoring lakes and streams. Vol. 14,pp 34, West African Ecology.

[14] Musah, E. (2009). sociological and Ecological impacts of sand and Gravel Mining. Journal of Environmental protection Agencies (Accra) Ghana. Vol. 1. Page 1-36.

[15] NISA (1997). The impact of dust on the environment. New York: W. H. Freeman and Company. pp. $17-18$.

[16]U.S. Environmental Protection Agency. (1999). Drinking Water and Health: What You Need to Know. Office of Groundwater and Drinking Water, EPA 816K99-001.

[17] USGS (2002). Potential Impacts of Quarrying stone in Karst- A literature Review. U.S Geological Survey Open-file Report OF-01-0484. http://geology.cr.usage.cov/pub/ofrs/OFR-01-0484

[18] UNEP (1999). United Nation Environmental Programme

[19] Water-Aid Ghana. (2008). Assessment of national sanitation policies: Ghana case. Final report." Accra: retrieved http;///www.wateraid.org

[20] WHO, (2010). Guidelines for drinking-water Quality. 